\title{
"Grow what you eat, eat what you grow": urban agriculture as middle class intervention in India
}

\author{
Camille Frazier ${ }^{1}$ \\ Clarkson University, USA
}

\begin{abstract}
In Bengaluru, India's "IT Capital" and one of its fastest growing cities, an increasing number of middle class residents are growing fruits and vegetables in their private spaces for home consumption. This article examines the motivations and practices of Bengaluru's organic terrace gardeners ("OTGians") in order to understand the possibilities and limitations of urban gardening as a middle class intervention into unsafe food systems and decaying urban ecologies. OTGians are driven primarily by concerns about worsening food quality and safety, and secondarily by the desire to create green spaces that counteract environmental degradation in the city. Like community gardeners in the Global North, they understand urban gardening as a way to mediate problems in the contemporary food system and the urban ecology. However, like other alternative food and environmental movements, OTGians' efforts are anchored in class-specific concerns and experiences. While they have been successful in creating a vibrant community, their efforts remain limited to the middle class. This is in large part due to the site, scale, and production practices that anchor their interventions. I briefly consider a different approach to food production in Bengaluru - that of a caste-specific farming community that has been dispossessed of much of its agricultural land in the name of urban development- to illuminate divergent histories, narratives, and practices of urban agriculture. However, I also emphasize the sites of intersection between these narratives, and suggest that OTGians can find commonalities with other food producers in the city in ways that might revolutionize Bengaluru's food future. I thus look for potential sites of collaboration and intersection in understanding the uneven power relations and politics of urban socio-natures.
\end{abstract}

Key words: Urban agriculture, gardening, food safety, urban development, urban environment, middle class, India

\section{Résumé}

À Bengaluru, une «capitale informatique» et l'une des villes à la croissance la plus rapide de l'Inde, un nombre croissant de résidents de la classe moyenne cultivent des fruits et légumes dans leurs espaces privés pour la consommation domestique. Cet article examine les motivations et les pratiques des jardiniers biologiques de Bengalurus en terrasses («OTGians») afin de comprendre les possibilités et les limites du jardinage urbain en tant qu'intervention de classe moyenne dans des systèmes alimentaires dangereux et des écosystèmes urbains en décomposition. Les OTGians sont principalement motivés par les préoccupations concernant la détérioration de la qualité et de la sécurité des aliments, et secondairement par le désir de créer des espaces verts qui contrebalancent la dégradation de l'environnement dans la ville. À l'instar des jardiniers communautaires du Nord globale, ils considèrent le jardinage urbain comme un moyen de résoudre les problèmes du système alimentaire contemporain et de l'écologie urbaine. Cependant, à l'instar d'autres mouvements alimentaires et environnementaux alternatifs, les efforts des OTGians sont ancrés dans des préoccupations et des expériences propres à chaque classe. Bien qu'ils aient réussi à créer une communauté dynamique, les efforts des OTGians restent limités à la «classe moyenne». Ceci est en grande partie dû au site, à l'échelle et aux pratiques de production qui ancrent leurs interventions. Je considère brièvement une approche différente de la production alimentaire à Bengaluru - celle d'une communauté agricole à une caste qui a été

\footnotetext{
${ }^{1}$ Dr. Camille Frazier, Assistant Professor of Anthropology, Department of Humanities and Social Sciences, Clarkson University, USA. Email: frazier.camille "at" gmail.com. This research was made possible with support from the FulbrightHays Doctoral Dissertation Research Abroad program, the UCLA International Institute, and the UCLA Asia Institute. Thank you to my interlocutors in Bengaluru who were generous with their time and knowledge and who welcomed me into their gardens. Thank you also to Prof. Josiah Heyman and the anonymous reviewers for their helpful comments on this article.
} 
dépossédée d'une grande partie de ses terres agricoles au nom du développement urbain - pour éclairer des histoires, des récits et des pratiques d'agriculture urbaine divergentes. Cependant, je souligne également les sites d'intersection entre ces récits, et je suggère que les OTGians peuvent trouver des points communs avec d'autres producteurs de la nourriture dans la ville d'une manière qui pourrait révolutionner l'avenir alimentaire de Bengaluru. Je cherche donc des sites potentiels de collaboration et d'intersection pour comprendre les rapports de force inégaux et la politique des socio-natures urbaines.

Mots clés: Agriculture urbaine, jardinage, sécurité alimentaire, développement urbain, environnement urbain, classe moyenne, Inde

\section{Resumen}

En Bengaluru, la capital de IT en India y una de las ciudades con más alta tasa de crecimiento, un creciente número de residentes de clase media están produciendo frutas y vegetales en sus espacios privados para consumo en el hogar. Este artículo examina la motivación y las prácticas de las terrazas de hortalizas orgánicas de Bengaluru. ("OTGians") para entender las posibilidades y limitaciones de los huertos urbanos como una intervención en poblaciones de clase media con sistemas alimentarios inseguros y con ecologías urbanas decadentes. Principalmente, OTGians se basa en las preocupaciones acerca de la calidad y seguridad de los alimentos, y, en segundo término, por el deseo de crear espacios verdes para abordar la degradación ambiental en la ciudad. Similar a las hortalizas comunitarias que ocurren en el Norte Global, ellos entienden a la hortaliza como una manera de mediar los problemas del sistema alimentario contemporáneo con la ecología urbana. Sin embargo, como cualquiera de los otros movimientos de alimentación alternativa y ambientales, los esfuerzos de OTGian se anclan en las preocupaciones y experiencias de una clase específica. Mientras que han sido exitosos en crear una comunidad vibrante, los esfuerzos de OTGians se mantienen limitados a una clase media. Esto se debe en gran parte al lugar, a la magnitud de la escala, y a las prácticas de producción que anclan sus intervenciones. Aquí considero brevemente un enfoque diferente a la producción alimentaria en Bengaluru el cual es específico a la comunidad de hortaliza de casta que ha sido desposeída de gran parte de su tierra agrícola en favor del desarrollo urbano - para iluminar historias divergentes, narrativas, y prácticas de la agricultura urbana. Sin embargo, también enfatizo acerca de los sitios de intersección entre esas narrativas, y sugiero que los OTGians pueden encontrar puntos en común con otros productores de alimentos en la ciudad a través de formas que podría revolucionar el futuro alimentario de Bengalaru. Por lo tanto, yo busco sitios potenciales de colaboración e intersección para el entendimiento de las relaciones de poder desiguales y las políticas de naturaleza urbano-social.

Palabras clave: Agricultura urbana, hortalizas, jardinería, seguridad alimentaria, desarrollo urbano, clase media, India.

\section{Introduction}

The organic terrace gardening workshop had drawn a larger crowd than expected, and volunteers were busy placing additional plastic chairs at the back of the room. The attendees sat facing a projected image of a dinner plate full of pill capsules of different shapes and colors. The slide read, "Future of Food?" The workshop organizer spoke above the hum of the projector: "If you want to eat like this, you just keep doing what you're doing, taking vitamins for this, a tablet for that. But if you want change, you have to grow and eat your own food."

This article examines efforts to "grow what you eat, eat what you grow" in Bengaluru (also known as Bangalore $)^{2}$, India's "IT capital" and one of Asia's fastest growing cities. With an urban population that tops 9.5 million and a decadal growth rate of 46.68\% between 2001 and 2011 (Government of India 2011), Bengaluru's rapidly expanding cityscape has displaced nearby farming communities (Goldman 2011) and created new environmental challenges, from reduced tree cover to degraded water sources (Ramachandra and Kumar 2010; Unnikrishnan and Nagendra 2014). In this context, an increasing number of middle class residents in Bengaluru are growing fruits and vegetables for home consumption, motivated primarily by concerns about worsening health and food safety conditions, and secondarily by declining green spaces in the city. These

\footnotetext{
2 The city's name was officially changed from Bangalore to Bengaluru in November 2014.
} 
concerns are best understood in relation to processes of rapid urban development that have transformed how middle class residents understand their food and urban ecologies, and the effects of these ecologies on their health. What is at stake in organic terrace gardeners' efforts is much more than producing food for individual families - for these gardeners, the terrace garden provides a site of intervention into unhealthy and untrustworthy food sources and decaying urban ecologies.

This article draws on data from eighteen months (June 2014 - January 2016) of participant observation at urban gardening fairs and workshops and interviews with organic terrace gardeners, most of whom selfdescribe as "OTGians", a title that originated with the Organic Terrace Gardening (OTG) Facebook group. I consider the motivations for organic terrace gardening among urban middle class residents of Bengaluru, comparing them with historical forms of gardening and food production found in the city. I ask, what motivates middle class individuals to take up organic terrace gardening? How do organic terrace gardeners' efforts compare with other forms of urban food production? What do these junctures and tensions teach us about the possible futures of urban agriculture? I argue that OTGians use gardening to mediate the changing food networks and urban ecologies that they understand to have negative effects on themselves, their families, and their city. In so doing, OTGians have created a vibrant community dedicated to sharing resources and knowledge about urban gardening, with the goal of re-working existing relations of food production and consumption in the city. However, because OTGians' efforts are rooted in class-specific experiences of the transforming cityscape, the OTG community remains limited to the urban middle class, and has been unable to incorporate other gardeners and forms of urban agriculture into its vision for the city. This ethnographic examination of Bengaluru's OTG community provides insight into how the political ecology of food systems overlaps with urban middle class experiences and anxieties of a rapidly developing city in the Global South, and speaks to the possibilities and limitations of urban agriculture as a form of "civic ecology" (Krasny and Tidball 2015; Sokolovsky 2011).

\section{Terrace gardening as urban agriculture}

Political ecology offers a constructive framework by which to analyze the politics of food production in urban spaces. Scholars have traced food production, exchange, and consumption in order to understand the politics and ethics of global food systems, agro-environments, and social movements (Hayes-Conroy and Hayes-Conroy 2013; West 2012; Christiansen 2013; Siniscalchi 2013; for a discussion of the role of political ecology in food studies, see Cadieux and Slocum 2015: 29-30). Although agriculture in the Global South has been key to political ecology since its beginning (see Blaikie and Brookfield 1987), the political ecology of urban agriculture-especially in the context of rapid urbanization and shifting class relationships, concerns, and desires-remains a relatively small subset of the literature. Authors who do consider these themes often use the frameworks of urban metabolism to analyze urban food systems (Heynen 2006; Marvin and Medd 2006; McClintock 2010; Shillington 2013). In this paper, I focus less on socio-ecological processes themselves than on how these processes are experienced and mediated by a particular class segment of urban society.

My approach is influenced by Laura Shillington's (2013) analysis of fruit tree cultivation in Managua, Nicaragua as a practice that allows marginalized residents to claim their rights to the city. Like Shillington, I attend to urban gardening at the level of the individual household. Much of the existing scholarship on urban agriculture focuses on the use of vacant spaces in cities as the primary site of urban food production. In the Global North, these spaces are often configured as 'community gardens', and are motivated by issues such as distrust of the contemporary food system, desire to become self-reliant, interest in reclaiming and re-greening the city, and creating public space and community (Baker 2004; Chung et al. 2005; Hite et al. 2017; Morgan 2015; Nonini 2013; Poulsen et al. 2014; Rogus and Dimitri 2014; Sokolovsky 2011; Turner 2011; Wakefield et al. 2007). ${ }^{3}$ Analyses of urban agriculture in the Global South often offer macro-level accounts of structural

\footnotetext{
${ }^{3}$ Too often these analyses neglect a thoughtful examination of the class and racial exclusions present in urban agriculture initiatives in the U.S. (Tornaghi 2014). For example, Poulsen et al. give little consideration to why the majority of community gardeners in Baltimore are white, despite the fact that these gardens are most often situated in predominately black neighborhoods (2014). They briefly suggest that it is probably not race, but rather "income and a lack of experience
} 
readjustment, urban poverty, and development. They approach urban agriculture as a productive livelihood strategy that links rural knowledge with urban spaces and markets, often through rural to urban migration (Bryld 2003; Drakakis-Smith et al. 1995; Drescher 2004; Linares 1996; Simatele and Binns 2008). ${ }^{4}$

Neither of these perspectives accurately captures the situation in Bengaluru, where organic terrace gardeners are neither the urban destitute, nor-because they produce food in individual, privately owned home spaces-do they exactly resemble the community gardening movements of the Global North. Their motivations, however, are similar to those of community gardeners and other forms of food activism in the Global North, as mentioned above, including distrust of the global food system, concerns about production practices and their effects on human and environmental health, and desire to bring food production and green spaces to the city. Also, like many alternative food movements around the world, OTGians are embedded in broader structures of inequality that limit participation to those who have the time, space, and resources to access healthy and sustainable food (Cadieux and Slocum 2015; Guthman 2008; Hayes-Conroy and HayesConroy 2013; Pudup 2008; Slocum and Cadieux 2015).

The class specificities of the OTG community are made immediately apparent by the phrase used to describe their efforts: "organic terrace gardening." Specifically, this phrase marks practitioners as middle class for two reasons: first, it is an English phrase (I will return to this point later in this article); and second, it requires access to a privately owned space, whether the rooftop of an individual house or an apartment balcony, where plants can be grown for household consumption. ${ }^{5}$ In using these two factors to describe OTGians as middle class, I rely on the schema outlined by Fernandes and Heller (2006) that considers linguistic, caste, and educational inequalities as inseparable from class hierarchies in India. Despite the breadth of the lives and livelihoods captured in the term "middle class", I find it useful in highlighting the educational, linguistic, professional, and spatial forms of class distinction that characterize and are reproduced through the OTG community.

I use the term "terrace garden" to describe the gardening practices of the OTG community in order to mark its difference from other forms of household food production common in India today. The Kannada term kaithota (literally "hand garden") refers to kitchen gardens that are common in rural households, where women plant a few fruits and vegetables for consumption and flowers for religious worship near the edges of their home.

The term kaithota and the broader term thota, meaning garden or plantation, are sometimes used to describe urban home gardens. However, the majority of the people involved in the organic terrace gardening community, as detailed in this article, rely on the English phrase "terrace garden" to describe their food production practices. These practices vary widely, and terrace gardens run the gamut from a few pots on a balcony to an entire terrace full of plant beds (Figures 1, 2, 3).

\footnotetext{
with or interest in gardening" that accounts for this difference in participation (Poulsen et al. 2014, 80). For analyses that engage with racial and class inequalities, see Hite et al. (2017); Sokolovsky (2011) and White (2011).

${ }^{4}$ For two exceptions, see Premat (2012) and Archambault (2016). Premat examines the nuanced relationships between home gardeners and the state in Cuba, and Archambault considers love in plant-human relations among home gardeners in Mozambique.

${ }^{5}$ Poor urban communities also produce food in individual household plots (Nagendra 2016; Shillington 2013). However, in India, the term "terrace gardening" is specific to urban home spaces that belong to the middle and upper classes: the word "terrace" generally refers to the flat, walled cement rooftop of a house. The phrase "terrace gardening" captures a wider range of middle and upper class home spaces for food production, including apartment balconies and yards.
} 


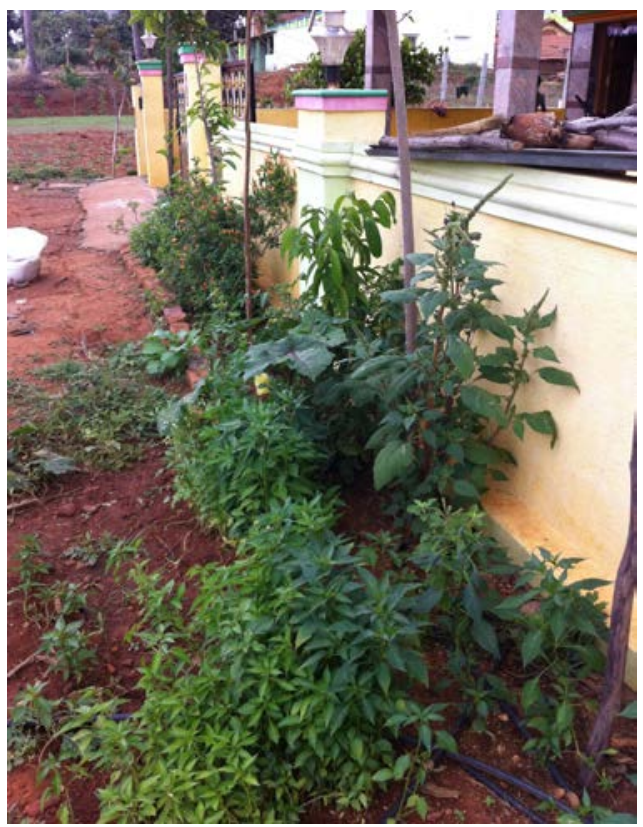

Figure 1: A rural household's kitchen garden that includes a diversity of plants for everyday use such as green chilies, eggplant, and flowering shrubs. Source: Author, 2015
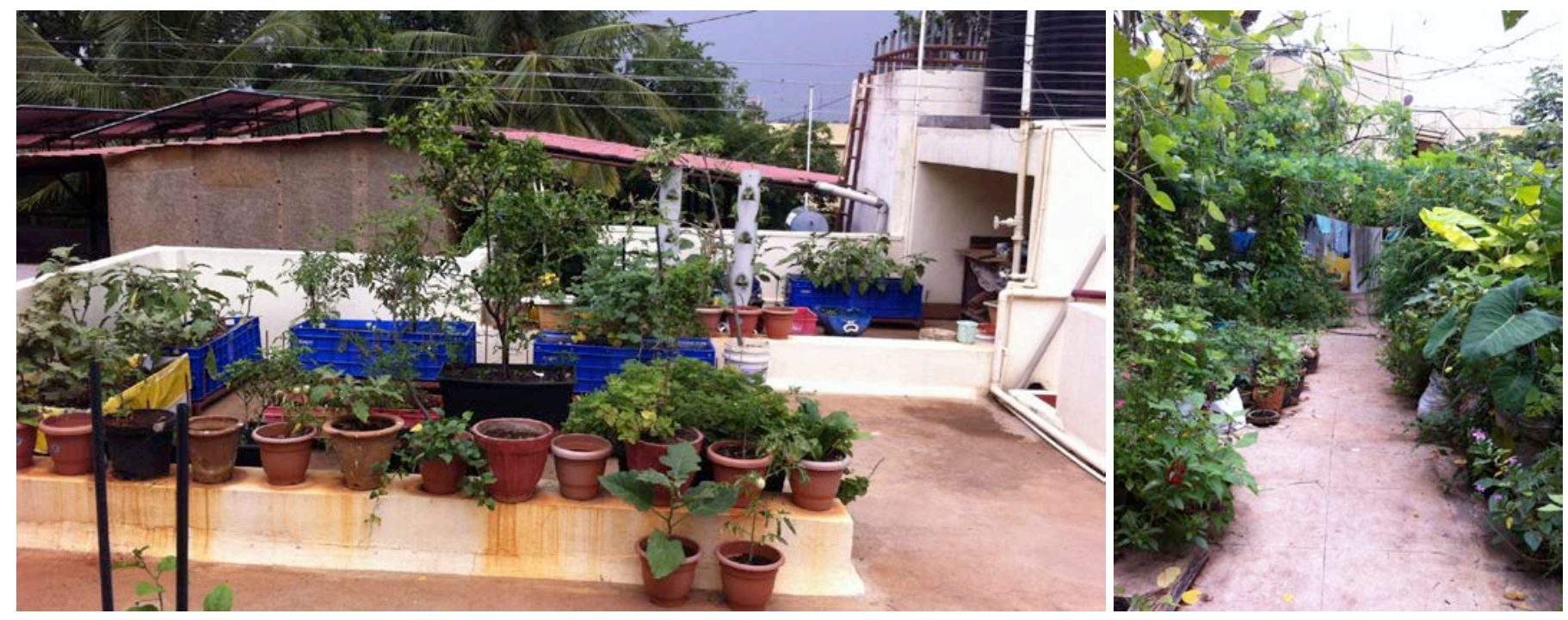

Figures 2 and 3: Two rooftop terrace gardens in Bengaluru. Source: Author, 2015

\section{Organic terrace gardening in Bengaluru}

"Start any idea from your house and your neighbors will follow", explained Anand, a founding member of one of the largest and best-known terrace gardening associations in India. During my fieldwork with the 
organization, attending fairs and workshops, I heard the story of his personal transformation several times: he had been a scientist at an agricultural university in Bengaluru, working on the propagation and uptake of Green Revolution technologies to manage pests. With time, he began to question the effects of these chemicalintensive methods for pest control. Today he is committed to spreading the word about the harmful effects of Green Revolution technologies and teaching alternative ways of food production and engaging with the natural world.

Several years ago, when his airplane was forced to circle above Bengaluru before landing, he noticed all of the bare rooftops littering the cityscape below. The experience gave him the idea to promote terrace gardening as both a way to decrease consumption of pesticide-laden fruits and vegetables and to add green spaces to the city. In 2005 he and a small group of urban professionals began conducting workshops, and in 2011 they created a trust focused on promoting organic terrace gardening in Bengaluru. Since then, the OTG community has grown into an extensive network. Much of the action is online, where the Organic Terrace Gardening Facebook group provides a space for OTGians to share successes and failures, ask questions and provide answers. At the time of writing, the OTG Facebook group has 30,562 members, and is full of photos from avid gardeners sharing images of their harvest or asking for answers about a particular pest or problem. The Facebook group is so popular that I waited several months before I was added as a member, despite being familiar with the organizers. When I approached one of them about it, he said that he rarely checks the OTG group anymore because he would have at least 300 requests every time, so he had stopped checking regularly. Perhaps to account for this, many locality-specific terrace gardening Facebook groups have sprung up: Bengaluru East Eerullies (BEEs; eerullies means onions in Kannada) and Basavanagudi Area OTGians, for example.

In addition to its online presence, the trust puts on trimonthly fairs that rotate to different parts of Bengaluru called Oota From Your Thota (with the first and last words translated from Kannada, the phrase means "food from your garden") (Figure 4). The events are popular and well attended, and the organizers estimate that they have around 5,000 visitors during each single-day event (Figure 5). They are also popular with vendors; the organizers generally accept sixty vendors per fair and there is always a waiting list. The vendors are mostly new companies that were established to meet urban interest in gardening, and offer products like self-watering pots and composting bins. The Oota From Your Thota fairs are meant to aggregate in one place everything necessary to start an organic terrace garden, and is successful in this regard-visitors can find everything from seeds to plastic pots to seedling trays to cocopeat (shredded coconut husk, mixed with potting soil). The goal, as the organizers explained it, is to promote a "holistic transition" to an organic lifestyle centered on the motto, "grow what you eat, eat what you grow."

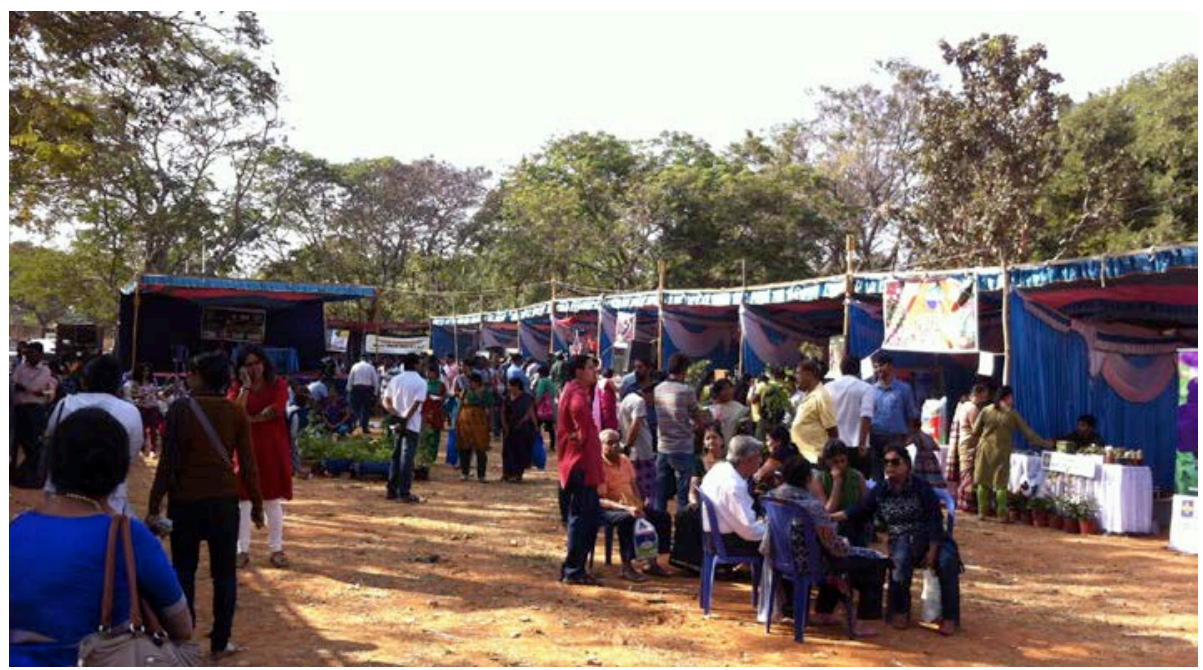

Figure 4: View of the stage and a row of vendor booths at Oota from your Thota. Source: Author, 2014 


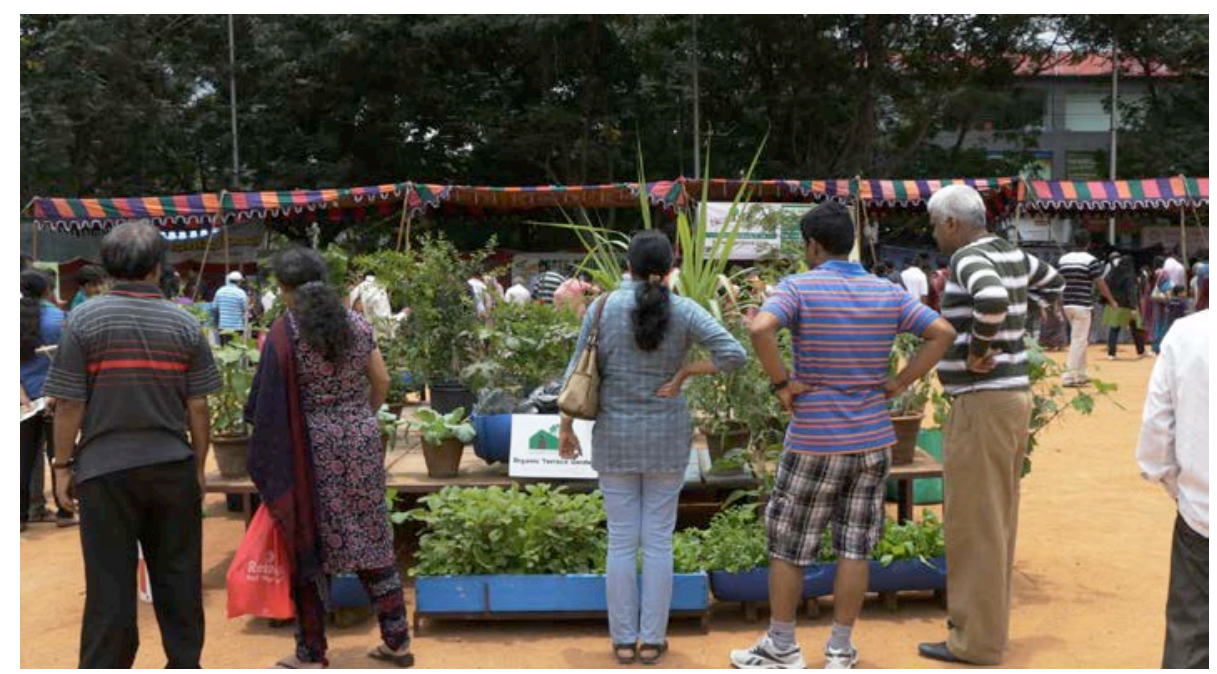

Figure 5: Oota from your Thota attendees admiring the display of container plants. Source: Author, 2014

As with the phrase "terrace gardening," language is one of the key ways in which these fairs are marked as middle class events. I volunteered at an Oota From Your Thota event a few weeks after moving to Bengaluru and was charged with staffing the registration booth. My role was to ask attendees to fill out a basic questionnaire with their name, contact details, location in the city, and whether they currently had a terrace garden. The sheet was in English, and since I wanted to be prepared and make sure my Kannada would be adequate, I asked one of the organizers if I was translating the questions correctly. He seemed surprised I was asking, and told me not to worry about using Kannada. I quickly realized why he was surprised by my question, because every person who came to the booth spoke English. English was the primary language at these events-workshops, handouts, and vendors' signs were in English, and while I would overhear other languages like Hindi and Kannada, these were less common than conversations in English. ${ }^{6}$

Language is a site of conflict in Bengaluru that represents larger battles over the future of the expanding city (see Nair 2000). It reflects educational and professional exclusions that mark class differences and concern about the influx of outsiders (of different class positions) into Bengaluru. From its name alone, the Oota From Your Thota fairs are implicated in these shifts, both as evidence of them as well as counter-strategies for maintaining the city that existed in the past. In a February 2016 article in The Hindu newspaper titled 'Bengaluru's growing pride', the author summarizes the links between the city's past and present, linguistic culture, and class-based forms of belonging:

Garden city is grafted with IT city, to create the new-age urban farmer who harnesses technology and knowledge to grow a green organic spread...Oota From Your Thota (OFYT) is a perfect phrase. It captures so much about Bengaluru—mingling of languages, aspirations to grow and eat fresh food from your garden, harking back to the Garden City, multi-pronged efforts towards the revival of that green status. It is also a great encouragement to get green-thumbed. It is becoming clearer that the idea of sustainable living, eating safe, knowing what you consume and put back into your planet have caught people's imagination and attention. (Bhumika 2016)

\footnotetext{
${ }^{6}$ See Baker (2004, 316-317) for a brief description of a seed sharing event in Toronto that alienated many Chinese gardeners because the event was held in English.
} 
In such descriptions of the OTG community, the city's burgeoning class of IT professionals becomes linked with specific histories and futures of the city.

The transforming cityscape is one of decay and possibility, and OTGians often grapple with the ambiguities of urban development. Many are professionals working in the information technology (IT) and information technology-enabled services (INES) industries. As such, they embody the aspirations and insecurities of the burgeoning middle class, from the clothes they wear to the apartment buildings they call home. At the same time, however, they express concern about the longevity of their careers and lifestyles. As one OTGian told me, the global economic downturn in 2008 convinced him that his career in the IT industry is less secure than being a farmer, since it does not ensure access to life's basic necessity-food.

Such feelings of insecurity are key to understanding the concerns that motivate the "grow what you eat, eat what you grow" philosophy and practice among Bengaluru's middle class. These concerns take two primary forms: first, and most critically, fear of the health effects of unsafe food and untrustworthy food producers; and second, an underlying concern about the loss of green spaces in the city. These concerns are linked with a desire to build community and to gain knowledge and experiences of nature that are otherwise believed to be lacking. In what follows, I first consider the community-building practices of OTGians. Then, I address two concerns that motivate organic terrace gardening as a middle class intervention: first, unsafe food and the unknown food producer; and second, the decline of food production and green spaces in Bengaluru. I then contrast OTGians' narratives of this decline with other experiences of food production and urbanization in the city in order to consider the possibilities and limitations of organic terrace gardening as a solution to the challenges in Bengaluru's shifting food ecology. I suggest that while the OTG community creates space for knowledge sharing and community building, their narratives and practices remain specific to the middle class and neglect other, co-present forms of urban food production. I conclude by suggesting that a more inclusive approach to urban agriculture would broaden the scope of OTGians' efforts.

\section{Building community}

Despite being a largely private pursuit, in one's private space, organic terrace gardening a platform for OTGians to make connections with one another online and in person through seed meetings, workshops, and events. The ethics of education and sharing of knowledge and resources are central to the terrace gardening community in Bengaluru. The information shared in these workshops ranges from the bio-pesticides that are most effective for certain pests, how to prepare the right combination of growing media, the growing periods for different fruits and vegetables, and how to source and save nati (native) seeds.

Outside of these more formalized workshops and fairs, organic terrace gardeners in different parts of the city have created sub-groups via social media that meet on a regular basis to share information and exchange seeds and other inputs. As the founder of the first such group told me, he wanted to create a space where people could set aside time to meet and exchange seeds so that the organic terrace gardening principles could be spread at the "grassroots" level. Through Facebook, I heard about a seed exchange that would kick-start a new subgroup of the OTG community for residents of the Eastern neighborhoods of the city. In the weeks leading up to the event, there was a flurry of arrangements on the event Facebook page, with people advertising the seeds and seedlings they had to give away and others requesting particular items.

When I arrived at the chosen location—a lakeside park near the city center—on the day of the exchange, the group was easily recognizable. There were clustered around a table covered with seedlings of various kinds, and as I walked up, a woman called out, "who asked for earthworms?" She extended a small plastic takeout container with soil and earthworms above her head. After someone claimed the worms, she pulled out water lily stems, drawing excited requests from the group. She dropped the plants into plastic bags and handed them over one by one. Someone teased her, "you said no plastic!" She agreed, but said, "with water plants, there's no option." 


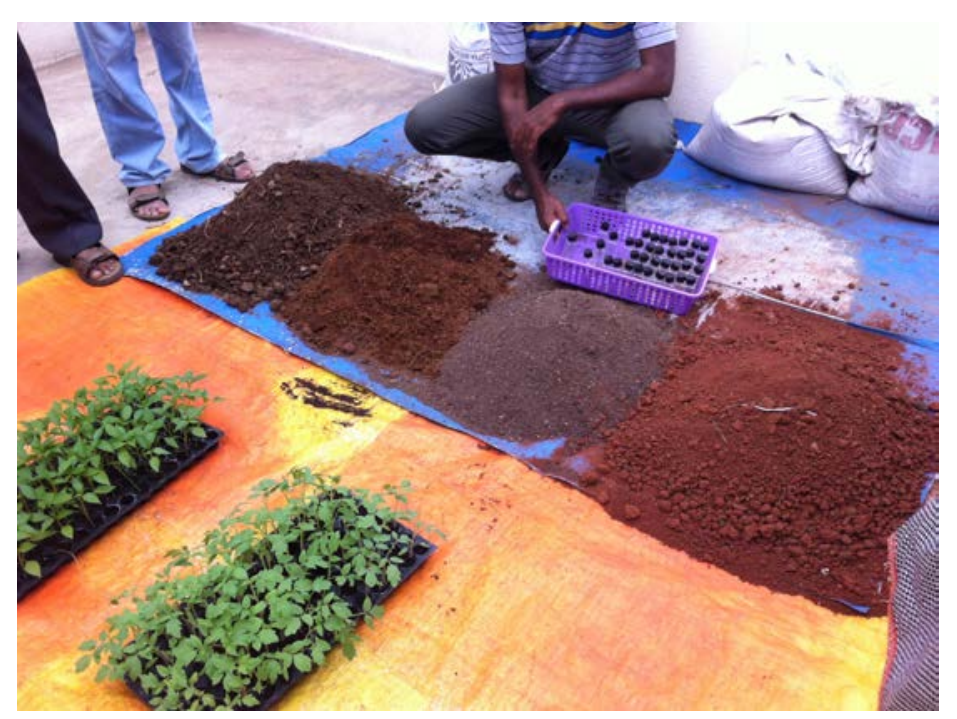

Figure 6: A growing media, seed, and potting demonstration at an organic terrace gardening workshop. Source: Author, 2015

The energy at these events was contagious, and created a sense of community centered on the excitement and pleasure, as well as the challenges, of terrace gardening. In general, securing organic inputs (fertilizer, seeds, etc.) was a common struggle around which individual terrace gardeners would coalesce and work together. During the introductions at the seed exchange, a woman shyly explained said that she had gone to an Oota From Your Thota fair months ago and had purchased a variety of seeds, but then realized that she had no idea where to start. She was having trouble, and was happy to have found this group. She said that she had started growing with some "organic" fertilizer she had bought, but she later learned that it was actually "chemical" fertilizer, and that was why she was having so many problems. The other attendees nodded in shared understanding, and a few suggested reliable sources for organic fertilizer.

The struggle to find the right kind of input was a common one, and often brought the organic terrace gardening community together in a shared pursuit. It also offered a collective way to laugh at their fellow urban gardeners - the fact that cow dung (a critical organic input in India) is available in powdered form on Amazon.in was a topic brought up at many workshops, arousing a collective chuckle (and a few scoffs) from the group. These events created space for gardeners to talk, laugh, share frustrations, and offer support and advice. Such community-building and knowledge-sharing activities were critical to the specific cultivation practices of OTGians-namely, growing foods organically without the use of chemical pesticides and fertilizers. While this caused challenges for gardeners, especially in terms of pest control, it was foundational to the OTG community (as the name would suggest). Concerns about pesticide overuse motivated the majority of OTGians to take up gardening.

\section{Fears about food safety}

The detrimental health effects of pesticide residues are a common topic in Bengaluru today, and appear often in news media as well as day-to-day conversation. There is a range of ways in which urban consumers attempt to manage these dangers, and organic terrace gardening has become one of the most visible. Pesticide contamination was one the first topics of conversation in every terrace gardening workshop I attended, whether conducted by Anand's trust, the Karnataka Department of Horticulture, or companies selling ready-to-grow kits for beginners. In two of these, the same image was used: a baby crying with its eyes closed and fists balled, its horrendously large head taking up the majority of the photograph. The image is of a baby from Kerala, and as the presenters explained, its deformity is the result of overuse of the pesticide endosulfan in a particular area in Kerala. Narratives of the deformities in Kerala due to endosulfan poisoning were common among activist 
circles working against the effects of the Green Revolution, and even made an appearance in Aamir Khan's popular television program discussing social issues, Satyamev Jayate (2012). An example of the many stories that appeared in the English language press, one article in The Times of India titled "Poison on Your Platter: Even the veggies you eat may be unsafe" (Rohith 2015) suggests that the "tantalizingly inviting" vegetables in the market are "toxic" with pesticides.

Concern over pesticide residues and the health consequences of conventional agriculture appeared time and again in my interactions with organic terrace gardeners. As one woman at a terrace gardening workshop stated, her reason for attending the workshop was to learn how to start a garden at her parents' house since her parents have "some or the other ailment or some kind disease" and she was confident that it was because "the water and the food they eat was full of pesticides." The workshop organizer responded that this kind of worry is what inspired the "grow what you eat, eat what you grow" message- - their goal is to bring attention to the positive health consequences of organic terrace gardening. According to many terrace gardeners, growing your own food is one of the only ways to be sure that you are safe from the harmful effects of chemical-laden produce.

Due to the dangers of pesticides and other chemical inputs like urea (these are often conflated under the term "chemicals"), an organic method of production is central to how terrace gardening is practiced in Bengaluru today. The term "terrace gardening" is almost always assumed to be "organic." This is not only true in the events put on by Anand's trust, which is explicitly against the technologies of the Green Revolution, but also in government programs and corporate product lines aimed at urban terrace gardeners. In a Department of Horticulture organic terrace gardening workshop, the scientist who led a presentation about cultivation methods began with a slide titled "poisonous vegetables." However, he was quick to point out that the organic methods discussed in the workshop were intended for urban terrace gardening only, because organic production is ineffective for "real farmers" who are worried about yield. So, he suggested, the only way to stay chemicalfree is to grow your own fruits, vegetables, and medicinal plants.

A suite of fears and ethical commitments often accompanies organic discourses and practices. Chemical-intensive agriculture, genetically modified organisms (GMOs), non-native and hybrid seeds, and processed foods are often conflated as equally pernicious. In closing the stage program at one of the June 2015 Oota From Your Thota event, Anand said that he had just two requests for the attendees: 1) grow as much as possible in your terrace garden, and throw out as little waste as possible; and 2) do not buy "processed foods", and avoid foods like maize and soy, since we "don't know where they're coming from" and "if they're from the US then they're GM" (genetically modified), so it is better to avoid processed foods altogether. As this closing statement illustrates, transnational discourses about organic agriculture and its associated commitments and concerns, such as opposition to genetic modification, inform conversations around terrace gardening.

While at the seed exchange discussed above, two young men approached the group to advertise the International Yoga Day festivities that would be happening in the park the following day. They were handing out fliers, and explained they were from the BJP (the political party of the current Prime Minister, Narendra Modi, who was credited with — and critiqued for-establishing the first-ever International Yoga Day). They explained that while walking through the park, they overheard our meeting and were very happy to see such activism around the issue of organic food, which they support. In response, a vocal middle-aged woman pointed her finger at the young men, saying, "you tell [Prime Minister] Modi that we don't want any GM [genetic modification]." One of the young men replied that they agree with her, but it is a very complicated issue. The woman retorted, "if GM, no PM!" Everyone in the seed exchange group laughed and clapped. The two BJP spokesmen smiled uncomfortably, said thank you for your time, wished the group well with its efforts, and quickly finished their work of handing out fliers advertising International Yoga Day. At the time I was surprised by the interaction, because I had not yet realized how important the GM issue was to members of the organic terrace gardening group. As I attended more events and spoke with more gardeners, I came to understand that organic terrace gardeners emphasized a range of issues that they saw as interconnected, primarily those surrounding Green Revolution and "New Green Revolution" technologies and methods.

It is not only these interlinked concerns about GM and chemical overuse that worry organic terrace gardeners, but also their inability to "trust" food producers. Specifically, they are concerned about whether 
produce sold as "organic" is pesticide-free. Such fears are explicitly linked to the work of unscrupulous actors who are careless about pesticide levels and their impact on consumers' health. There is a growing sense that what consumers see on store shelves has been manipulated in ways that make these food items dangerous. The anxieties about food safety and health are therefore closely interlinked with feelings of distrust of food sources.

While at a day-long terrace gardening workshop, I struck up a conversation with a man who had been participating actively in the workshop and seemed particularly engaged. In answering my question about what motivated him to attend the workshop, he explained that he began gardening about three months ago when his wife started buying organic products. He argued with her that if they were going to be paying more for their food, he wanted to know whether he could "trust" that the organic products are "really organic." At the time his wife responded that the organic farms let customers visit them so you can see for yourself. But, he explained, even if he took the time to visit these farms, "what knowledge do I have to find out if it is an organic food or not?"7 So, he decided to instead grow his own organic vegetables, as this was the only way he could have full confidence that what he consumed was truly organic.

This example illustrates that it is not only skepticism of conventional food sources, but also of organic produce that motivates organic terrace gardening. A distrust of organic certification pervades organic terrace gardening discourse-as gardeners told me on several occasions, how can you be sure that organic is actually organic? Even if a product is certified, there is no guarantee. More effective than certification is "trust" and "belief" in a particular farmer or group. But because this does not come easily to urban residents, who find it hard to build direct relationships with food producers, the best course of action is to grow your own food so that you can be absolutely sure about its quality. The separation between food producers and consumers, which allows for unscrupulous practices on the part of the food producer or manufacturer, is explicitly linked to feelings of distrust and fears about food quality, and is a key motivation among OTGians.

\section{Cultivating and connecting with nature}

While concern about food safety was the primary motivation for the majority of OTGians, many also emphasized the role of their terrace gardens in creating nature spaces in the city. Srinath's "urban jungle" offers a good example. His house, located in an upper-middle class neighborhood in Bengaluru, was immediately recognizable from the street-its walls were completely covered with lush green vines with big purple flowers. During my tour of his rooftop garden, Srinath told me that he continually tried to use more and more of the space along the edge of his property for his "jungle," but his neighbors did not want him to plant anything along the curb because it would reduce parking. He explained that he is gardening to "go against the norm." Srinath was "against the norm" in more ways than one-the son of a poor farmer, he had struggled to attend school as a child, but built a successful career as a consultant. When we met, he had just established a consulting firm focused on supporting socially responsible companies. As we walked through his garden, Srinath pointed out that he was creative in using every kind of object he could find to grow plants - sprinkled among the terracotta pots were old grocery and cement bags (doubled up so that they would last), a bathtub full of water plants, and even a toilet bowl. Showing me the wide array of plant varieties, Srinath explained why he is so committed, despite his neighbors' complaints: this is his passion, and his favorite part is building a "whole ecosystem." He loves the birds, insects, monkeys, and stray dogs and cats that come to enjoy his garden.

Building "ecosystems" and creating connections with "nature," especially for urban children who otherwise lack access to such experiences, were primary motivations for organic terrace gardeners. Both men and women emphasized the joy in bringing their children into their gardens, showing them "where food comes from." For middle class children growing up in apartment complexes and tightly packed urban layouts, access to this knowledge is limited. Their parents understood this alienation from nature and food sources as damaging to children's development, and organic terrace gardening became one way for urban middle class families to fill these gaps in their children's education. At an organic gardening workshop, one man told me that he started

\footnotetext{
${ }^{7}$ Interest among urban consumers in visiting farms has been on the rise. One organic producer company began charging INR 300 per visit to their vegetable farmers' fields because the demand to do so was so high it was taking up too much of the coordinator's and farmers' time. When I spoke with a company employee in October 2015, they had already made INR 5,000 in just one and a half months of charging visitors.
} 
his small garden so that he could be sure he was eating organic food. He quickly found, though, that his favorite part of gardening was bringing his daughter with him to work in the garden. He was happy that she was able to experience nature and learn about food.

OTGians' narratives about connecting with nature and food through gardening are best understood in relation to Bengaluru's particular history as India's 'Garden City.' This common nickname for the city is the result of interlinked histories of kings, caste communities, the colonial state, and postcolonial imaginings of the city and nation (Nagendra 2016; Nair 2005; Srinivas 2004). Lalbagh, an immense botanical garden at the center of the city, has its beginnings in the mid- $18^{\text {th }}$ century and is credited to Haider Ali and his son, Tipu Sultan, the last Muslim ruler of the Kingdom of Mysore (Srinivas 2004: 23). Lalbagh began as an Islamic pleasure garden that lay outside the central fort and city area established by Kempe Gowda in 1537. After the British takeover of the city in 1799, Lalbagh passed through a few different forms of colonial oversight before it became part of the Agri-Horticultural Society of India in 1839 under Sir Mark Cubbon, who also founded the extensive Cubbon Park that today sits at the heart of Bengaluru. During the period of British rule, Lalbagh became a site for cultivation of both horticultural diversity and class- and race-based distinction; its glass house was the site of tea parties intended to bring refinement to the city, and its director, German botanist Gustav Hermann Krumbiegel, used gardening competitions to inspire recreational horticultural cultivation among home owners in the city (Mathur and Cunha 2006; Nagendra 2016; Srinivas 2004).

These gardens become class-specific sites of nostalgia in the transformed cityscape and they are central to organic terrace gardeners' understandings of Bengaluru's decay. Among the very first slides in Anand's introduction to his terrace gardening workshop was a picture of traffic in Bengaluru. He paused on the image, suggesting that the city has become "too big." He suggested that with the "IT invasion of Bangalore" a lot has changed - 35 to 40 years ago every house had an ornamental garden in the front and a kitchen garden in the back. Now, the city has lost its greenery. Each terrace gardening workshop that I attended and every urban gardener with whom I spoke referred to how dense the cityscape had become and how much of its gardens and green spaces had been lost. For example, Shruthi was committed to growing a terrace garden so that her children could spend time playing with soil and being in natural spaces. She remembered having this opportunity herself as a child in a (then) sleepy neighborhood of Bengaluru, and was worried that her children would not have access to the same kinds of experiences.

In focusing on gardening as a way to "grow what you eat, eat what you grow," OTGians offer a critique of unbridled urbanization that emphasizes the importance of creating and maintaining green spaces not only for leisure, but also for food production. In so doing, they challenge a vision for the Garden City that focuses on urban nature spaces as sites of recreation rather than livelihood (Unnikrishnan and Nagendra 2014). However, by lamenting the loss of the bungalow home and private garden in their descriptions of urban transformation, Anand's and Shruthi's comments point to a very particular version of the Garden City, one that reflects the divergent meanings of the word "garden." Smriti Srinivas suggests that understandings of the garden changed between the pre-colonial and colonial periods in Bengaluru. Specifically, gardens in the precolonial period "were essentially horticultural lands where a variety of fruits, flowers, and vegetables were produced for the urban centers," while "gardens built by the British were large or small grassy parks with trees and flowers and surrounded by suburban bungalow houses with their own green spaces (Srinivas 2004, 47-8). Imagined as the loss of bungalow gardens, Shruthi's and Anand's descriptions of the declining cityscape are rooted in a class-specific experience of Bengaluru, one that extends from the pre-colonial and colonial past to the forms of postcolonial urban development in the city that privileged middle class spaces, concerns, and desires (Nair 2009). Those who produced food commercially for the city have a different history of the garden city and a different experience of decayed garden spaces.

\section{Class and caste in the garden}

The bungalow gardens that form the basis for nostalgia among organic terrace gardeners, and the labor required to make and maintain them, are quite different from the gardens that historically fed the city. Shortly after my arrival in Bengaluru, I started to hear about the Vahnikula Kshatriya (also known as the Tigala) caste, renowned for its horticultural prowess. The Vahnikula Kshatriya community is responsible for the Karaga 
festival, one of the city's largest and most famous religious events. The caste falls under the OBC, or Other Backward Classes category established by the Constitution of India. The OBC category includes lower (but not the lowest) castes that have historically been disadvantaged and today receive a certain percentage of reserved positions in public sector employment and education. ${ }^{8}$ For many years Vanniyakula Kshatriya members were the primary horticultural producers for the city, and to this day are known for their gardening and landscaping skills. They owned farmland near the city's manmade lakes and supplied much of the food sold to urban consumers. But over time, as the priorities of urban development changed, the land where Vanniyakula Kashtriyas cultivated food was put to uses that largely excluded the community altogether, such as housing and transportation.

Chennappa, a retired government bureaucrat and leader in the Vanniyakula Kshatriya community, presides over a credit association office located on a narrow street behind the headquarters of the city government. While sitting at Chennappa's desk at the end of a long boardroom table, he explained to me that most of his community used to grow horticultural produce like fruits and vegetables for the Bengaluru market. But now, most of the community's land, especially nearby the city center, has been taken by the city government for "development." He described that earlier "eighty percent of Bengaluru land was cultivating and growing vegetable and fruits." This started to change in 1933 under British rule, when 210 acres of Vanniyakula Kshatriya lands were "acquired" for Cubbon Park, 110 acres for a housing colony, and 88 acres for developing a road. This began the process of displacement, and in 1938 things changed for the worse; "earlier to that [1938], on request they [city government authorities] used to take and develop the layouts," but later, "against the will of the agriculturalist they started acquiring." The trend continued after Independence in 1947, and in 1951 the City Improvement Trust Board (CITB) was founded (it is now the Bengaluru Development Authority); "they [the CITB], without giving any importance to the gardening and production of vegetables for the city, they acquired land. See this whole area, Sampanginagara, [was] growing fruits and vegetables. They acquired and closed it," Chennappa explained as he swept his hand around us, drawing in the association building and the surrounding area. His own family experienced this loss first hand, when their lands near Lalbagh were taken for urban development projects and he was forced to find wage labor.

At the most basic level, the stories of both OTGians and Vanniyakula Kshatriya farmers are narratives of loss. Of land captured by the expanding city, and unhealthy bodies and communities left behind. But the land, labor, and futures caught up in these stories diverge. These differences are linked with historical and class-specific definitions of what constitutes gardening in the city. For the British, who acquired Vanniyakula Kshatriya fields to create the immense and manicured Cubbon Park that separated the old city area from the British Cantonment, urban gardens were spaces for leisure, aesthetic beauty, and class refinement rather than food production. Smriti Srinivas (2004) traces these differences in her description of how gardening in Bengaluru changed over time:

Each [pre-colonial and colonial society] had its own version of what the 'garden' meant. In the first model, gardens were essentially horticultural lands where a variety of fruits, flowers, and vegetables were produced for the urban centers. The addition to this model was the pleasure garden of Haider Ali and Tippu Sultan that stood on the fringe of the City. In the second model, with the exception of the Lalbagh Botanical Gardens where 'indigenous' and 'exotic' species were cultivated, gardens built by the British were large or small grassy parks with trees and flowers and surrounded by suburban bungalow houses with their own green spaces. (2004: 4748)

By emphasizing food production, organic terrace gardeners' efforts do not fit easily into either of these categories of "garden" (see also Nagendra 2016: 77). Terrace gardeners offer a critique of unbridled urbanization that emphasizes the importance of creating and maintaining urban green spaces not only for leisure, but also for food production. Yet in promoting organic gardening in private residences for home

\footnotetext{
${ }^{8}$ The most marginal caste groups, the Dalit and tribal communities, are excluded from the OBC and instead belong to the "Scheduled Castes" and "Scheduled Tribes" categories respectively.
} 
consumption, their vision for urban agriculture differs from the historical and concurrent forms of food production among the Vanniyakula Kshatriya community.

\section{Conclusion}

Narratives of bungalows with decorative gardens in the front and kitchen gardens in the back conjure a particular experience of gardening in Bengaluru, one rooted in the very urban development that has displaced horticultural fields in favor of apartment complexes and individual homes. That being said, home gardens are the only kind of nature that is valued by OTGians. As described previously, a more general desire to counteract the loss of Bengaluru's green spaces is also central to organic terrace gardener's narratives of what motivates them to garden. However, in their descriptions of the Garden City's past, OTGians often reference a specific history of the city while remaining unspecific about when, by, and for whom the Garden City earned its name. By erasing the caste and class specificities of how the city was and is gardened, the OTG narrative represents middle class experiences of Bengaluru's decay as universal, and positions the greening of private spaces as the most prominent roadmap for the future. This further marginalizes the histories and futures of particular caste communities like the Vanniyakula Kshatriyas.

The founders of the organic terrace gardening trust are aware of the class inequalities in their efforts. I was often impressed by their self-critical reflections on their inability to challenge existing hierarchies. Anand admitted to me early on that their primary audience is middle and upper middle class families. He explained that upper class residents do not participate because "they leave everything to their servants" and are not interested in "doing things themselves", while the lower class is "too difficult to reach." Attempts to account for some of these class inequalities appeared in different ways during my interactions with the organization and its founders. For example, I learned that the trust had attempted to establish a gardening initiative targeted toward slum communities in Bengaluru. The idea was to introduce climbing vegetables, since vines can be trained up onto the roof of the small homes where they have sun and space to grow are therefore some of the few plants that can be grown in tightly packed slum neighborhoods. But Anand lamented that this initiative never got off the ground because they were unable to secure funding for the project. ${ }^{9}$

Despite such attempts at crossing the class divide, the ideologies and practices of urban food production among the OTG community produce a different, and in some ways contradictory, vision for the Garden City than that of the Vanniyakula Kathriya community. OTGians' commitment to organic production is a critical site of divergence between the OTG movement and other forms of urban food production. By emphasizing organic methods as a way to limit the harmful effects of chemically intensive agriculture, organic terrace gardeners distinguish themselves from urban farmers-many of whom are members of the Vanniyakula Kshatriya community - who produce for market and often rely on chemical fertilizers, pesticides, and water from sewage drains and contaminated lakes. Although these market-oriented urban gardeners also contribute to creating green spaces in the city and cut down on food miles, they do not fit into the OTG community's understanding of an ideal urban agriculture. Rather, they are a source of OTGians' anxieties: urban farmers who grow for the market are the very producers mistrusted by organic terrace gardeners, as they produce the chemical-ridden and contaminated fruits and vegetables that inspire the effort to "grow what you eat, eat what you grow."

OTGians are part of a vibrant and supportive community, but it is one predicated on individual rather than structural interventions. This is not to suggest that gardening in private rather than public spaces forecloses civic engagement (see Chung et al. 2005). Rather, it is to highlight that OTGians place responsibility for safe foods and healthy urban ecologies on individual households. Chennappa's description of the reasons why his caste community members continue to farm in small urban pockets and the city's outskirts—despite the

\footnotetext{
9 The struggle for funding speaks to the larger frustration many organic terrace gardeners feel toward the state and municipal government. As I encountered frequently during my fieldwork, non-governmental groups were quite disparaging of governmental efforts and vice versa.
} 
community's systematic exclusion and removal from the developing city-illuminates a different understanding of the role of food producers in urban spaces:

We feel that this is our family culture. We have to maintain it...Just imagine, one day vegetables [will] not [be in the] market. What are you going to do? We feel, and we satisfy [ourselves], we are producing something for the society...See, very healthy and good vegetables [community farmers are] growing and giving [selling] to society. And good fruits they're growing to give society. And green vegetables. Flowers! To ladies, women, and also to the temple. They are giving. But they do not have a piece of flower for their own [hair]. See, that is the condition. They do not have two saris to change, but they are giving healthy food to the society.

For Chennappa, this emphasis on their contributions to society means that Vanniyakula Kshatriya cultivation should be valued and promoted, and makes the economic inequalities that keep the community from enjoying the fruits of their labor especially frustrating. But he recognizes that certain kinds of knowledge and labor are more valued than others. In Chennappa's words, "nowadays it has become very difficult to lead a normal life. Because the software [industry] has come, everybody is educated, and our caste people are not well educated. Only middle class and rich peoples' sons, children are well educated." The solution to this problem, for Chennappa, will have to come from both the community—he works hard to encourage his fellow Vanniyakula Kshatriya parents to send their children to school, a point of tension in the community—as well as from government intervention. As he put it, "lip sympathy will not work."

In re-focusing attention on food production, and especially in emphasizing teaching and knowledgesharing around cultivation as a skill, OTGians call into question the priority given to the IT industry and other appropriately urban pursuits. They use gardening to create alternative spaces and practices of community building, and in so doing intervene in the food systems and urban ecologies about which they are concerned. In these ways, they offer an example of "civic ecology" (Krasny and Tidball 2015; Sokolovsky 2011). At the same time, however, organic terrace gardeners are members of the educated, English-speaking middle class that see their work in the terrace garden as an alternative to their professional work in the very industries that have displaced other cultivators from the city. The OTG community's intervention rests on the class-based inequalities in education, language, and types of work that have marginalized lower castes and classes from Bengaluru's past, present and future. They are in this way similar to other environmental interventions among India's urban middle class that often strengthen structural inequalities in the name of urban "greening" (Baviskar 2002; Mawdsley 2004; Veron 2006).

My goal in making this critique is to highlight a missed opportunity for collaboration across scales, practices, and sites of urban agriculture. In her review of the literature on urban political ecology, Anne Rademacher notes that there is a "constellation of competing and meaningful understandings of urban nature, each potentially located in a privileged or empowered social position at different moments" (2015: 138). She also suggests that these competing understandings can be "generative of new affinities, sometimes surprising political maneuvers, and distinctly moral social logics" (p. 142). There is space for such new affinities among food producers in Bengaluru. For example, Rajinappa, a young Vanniyakula Kshatriya man, explained to me that he would continue to farm his family's small plot of land next to an elevated highway overpass because it is important for him to have green spaces in his city. Rajinappa's dedication to building a verdant urban ecology is similar to that of many OTGians, and it is energizing to imagine Rajinappa's field and Srinath's "urban jungle" as part of a shared pursuit, one that opens space for possible collaborations across sites, scales, and practices of urban agriculture. 


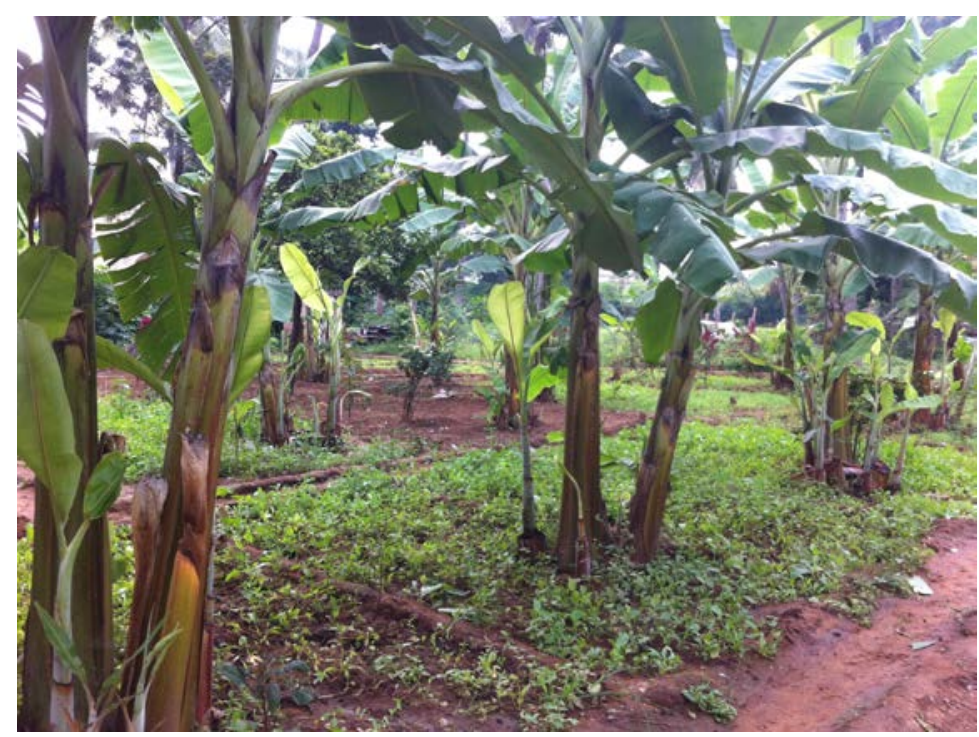

Figure 7: Rajinappa's garden, located next to a major highway overpass. Source: Author, 2015

OTGians have mobilized the concerns and experiences of the urban middle class in the service of building a community committed to organic terrace gardening as an answer to worsening food safety and declining green spaces in the city. OTGians are thus reevaluating and reworking the relationship between food and the urban ecology, and in so doing can generate new approaches to urban food security and sustainability. My goal, then, is not to diminish the transformative potential of organic terrace gardening, which, as this discussion has shown, creates space for alternative engagements with food and the city. Rather, my goal is to show that the class and caste distinctions that divide organic terrace gardening from other forms of urban agriculture have implications for the lives, livelihoods, and futures that are possible in the garden city. In the intersections of the concerns and desires of both the OTGians and other urban gardeners from other castes and classes, there is room to expand the meanings and practices of urban agriculture in Bengaluru, for the benefit of the city and its diverse communities.

\section{References}

Baviskar, A. 2002. The politics of the city. Seminar: a symposium of the changing contours of Indian environmentalism 516.

Bhumika, K. 2016. Bengaluru's growing pride. The Hindu. Feb 29.

Blaikie, P.M. and H.C. Brookfield. 1987. Land degradation and society. New York: Methuen.

Bryld, E. 2003. Potentials, problems, and policy implications for urban agriculture in developing countries. Agriculture and Human Values 20(1): 79-86. doi:10.1023/A:1022464607153.

Cadieux, K.V. and R. Slocum. 2015. What does it mean to do food justice? Journal of Political Ecology 22: $1-26$.

Christiansen, E.A.N. 2013. Negative externalities of food production: discourses on the contested Norwegian aquaculture industry. Journal of Political Ecology 20: 180-198.

Chung, K, R. J. Kirkby, C. Kendell, and J. A. Beckwith. 2005. Civic agriculture. Culture and Agriculture 27(2): 99-108. doi:10.1525/cag.2005.27.2.99.

Drakakis-Smith, D, T. Bowyer-Bower, and D. Tevera. 1995. Urban poverty and urban agriculture: an overview of the linkages in Harare. Habitat International 19(2): 183-193. doi:10.1016/0197-3975(94)00065-A. 
Drescher, A.W. 2004. Food for the cities: urban agriculture in developing countries. International Conference on Urban Horticulture. Acta Horticulturae 643: 227-231.

Fernandes, L. and P. Heller. 2006. Hegemonic aspirations: new middle class politics and India's democracy in comparative perspective. Critical Asian Studies 38(4): 495-522. doi:10.1080/14672710601073028.

Goldman, M. 2011. Speculative urbanism and the making of the next world city. International Journal of Urban and Regional Research 35(3): 555-581. https://doi.org/10.1111/j.1468-2427.2010.01001.x.

Guthman, J. 2008. Bringing good food to others: investigating the subjects of alternative food practice. Cultural Geographies 15(4): 431-447. doi:10.1177/1474474008094315.

Hayes-Conroy, J. and A. Hayes-Conroy. 2013. Veggies and visceralities: a political ecology of food and feeling. Emotion, Space and Society 6: 81-90. doi:10.1016/j.emospa.2011.11.003.

Heynen, N. 2006. Justice of eating in the city: the political ecology of urban hunger. In N. Heynen, M. Kaika and E. Swyngedow (eds.) In the nature of cities: urban political ecology and the politics of urban metabolism. New York: Routledge. Pp. 129-142.

Hite, E.B, D. Perez, D. D'ingeo, Q. Boston, and M. Mitchell. 2017. Intersecting race, space, and place through community gardens. Annals of Anthropological Practice 41(2): 55-66. https://doi.org/10.1111/napa.12113.

Krasny, M.E. and K.G. Tidball. 2015. Civic ecology: adaptation and transformation from the ground up. Cambridge, MA: MIT Press.

Linares, O.F. 1996. Cultivating biological and cultural diversity: urban farming in Casamance, Senegal. Africa 66(01): 104-121. doi:10.2307/1161514.

Marvin, S and W. Medd. 2006. Metabolisms of obecity: flows of fat through bodies, cities and sewers. In N. Heynen, M. Kaika and E. Swyngedow (eds.) In the nature of cities: urban political ecology and the politics of urban metabolism. New York: Routledge. Pp. 143-156.

Mawdsley, E. 2004. India's middle classes and the environment. Development and Change 35(1): 79-103.

McClintock, N. 2010. Why farm the city? Theorizing urban agriculture through a lens of metabolic rift. Cambridge Journal of Regions, Economy and Society 3(2): 191-207.

Morgan, K. 2015. Nourishing the city: the rise of the urban food question in the global north. Urban Studies 52(8): 1379-1394.

Nagendra, H. 2016. Nature in the city: Bengaluru in the past, present, and future. New Delhi: Oxford University Press.

Nair, J. 2000. Language and right to the city. Economic and Political Weekly 35(47): 4141-4146.

Nair, J. 2005. The promise of the metropolis: Bengaluru's twentieth century. New Delhi: Oxford University Press.

Nonini, D.M. 2013. The local-food movement and the anthropology of global systems. American Ethnologist 40(2): 267-75. doi:10.1111/amet.12019.

Poulsen, M.N, K.R.S. Hulland, C.A. Gulas, H. Pham, S.L. Dalglish, R.K. Wilkinson and P.J. Winch. 2014. Growing an urban oasis: a qualitative study of the perceived benefits of community gardening in Baltimore, Maryland. Culture, Agriculture, Food and Environment 36(2): 69-82. doi:10.1111/cuag.12035.

Premat, A. 2012. Sowing change: the making of Havana's urban agriculture. Nashville: Vanderbilt University Press.

Pudup, M.B. 2008. It takes a garden: cultivating citizen-subjects in organized garden projects. Geoforum 39(3): $1228-1240$.

Rademacher, A. 2015. Urban political ecology. Annual Review of Anthropology 44(1): 137-152. https://doi.org/10.1146/annurev-anthro-102214-014208.

Ramachandra, T.V. and U. Kumar. 2010. Greater Bangalore: emerging urban heat island. GIS Development 14(1): 86-104.

Rogus, S. and C. Dimitri. 2015. Agriculture in urban and peri-urban areas in the United States: highlights from 
the census of agriculture. Renewable Agriculture and Food Systems 30 (Special Issue 01): 64-78. doi:10.1017/S1742170514000040.

Shillington, L.J. 2013. Right to food, right to the city: household urban agriculture, and socionatural metabolism in Managua, Nicaragua. Geoforum 44 (January): 103-111. https://doi.org/10.1016/j.geoforum.2012.02.006.

Simatele, D.M. and J.A.B. Binns. 2008. Motivation and marginalization in African urban agriculture: the case of Lusaka, Zambia. Urban Forum 19(1): 1-21. doi:10.1007/s12132-008-9021-1.

Siniscalchi, V. 2013. Environment, regulation and the moral economy of food in the slow food movement. Journal of Political Ecology 20: 295-305.

Slocum, R. and K.V. Cadieux. 2015. Notes on the practice of food justice in the US: understanding and confronting trauma and inequity. Journal of Political Ecology 22: 27-52.

Sokolovsky, J. 2011. Civic ecology and the anthropology of place: urban community gardens and the creation of inclusionary landscapes. Anthropology News 52(3): 6. https://doi.org/10.1111/j.15563502.2011.52306.x.

Srinivas, S. 2004. Landscapes of urban memory: the sacred and the civic in India's high tech city. Hyderabad: Orient Longman.

The Times of India. 2015. Poison your platter: even the veggies you eat may be unsafe. June 9.

Tornaghi, C. 2014. Critical geography of urban agriculture. Progress in Human Geography 38(4): 551-567. doi:10.1177/0309132513512542.

Unnikrishnan, H. and H. Nagendra. 2014. Privatizing the commons: impact on ecosystem services in Bangalore's lakes. Urban Ecosystems 18(2): 613-632. https://doi.org/10.1007/s11252-014-0401-0.

Véron, R. 2006. Remaking urban environments: the political ecology of air pollution in Delhi. Environment and Planning A 38(11): 2093-2109. https://doi.org/10.1068/a37449.

West, P. 2012. From modern production to imagined primitive: the social world of coffee from Papua New Guinea. Durham, NC: Duke University Press.

White, M.M. 2011. Sisters of the soil: urban gardening as resistance in Detroit. Race/Ethnicity: Multidisciplinary Global Contexts 5(1): 13-28. 